\title{
Multiple sources: The pXRF analysis of obsidian from Kenan Tepe, S.E. Turke
}

DOI:

10.1016/j.jasrep.2016.10.014

\section{Document Version}

Accepted author manuscript

Link to publication record in Manchester Research Explorer

\section{Citation for published version (APA):}

Campbell, S., \& Healey, E. (2016). Multiple sources: The pXRF analysis of obsidian from Kenan Tepe, S.E. Turke. Journal of Archaeological Science: Reports, 10, 377-389. https://doi.org/10.1016/j.jasrep.2016.10.014

\section{Published in:}

Journal of Archaeological Science: Reports

\section{Citing this paper}

Please note that where the full-text provided on Manchester Research Explorer is the Author Accepted Manuscript or Proof version this may differ from the final Published version. If citing, it is advised that you check and use the publisher's definitive version.

\section{General rights}

Copyright and moral rights for the publications made accessible in the Research Explorer are retained by the authors and/or other copyright owners and it is a condition of accessing publications that users recognise and abide by the legal requirements associated with these rights.

\section{Takedown policy}

If you believe that this document breaches copyright please refer to the University of Manchester's Takedown Procedures [http://man.ac.uk/04Y6Bo] or contact uml.scholarlycommunications@manchester.ac.uk providing relevant details, so we can investigate your claim.

\section{OPEN ACCESS}


Title:

Multiple sources: the pXRF analysis of obsidian from Kenan Tepe, S.E. Turkey

\title{
Authors:
}

Stuart Campbell (Corresponding author: stuart.campbell@manchester.ac.uk) Elizabeth Healey

\author{
Address (both authors) \\ School of Arts, Languages and Culture, University of Manchester, Oxford Road, \\ Manchester M13 9PL, United Kingdom
}

\begin{abstract}
Obsidian is often seen as a proxy for exchange and networking even though the relationship between these elements can be somewhat indirect. Nevertheless, recent studies which involve the provenance analysis of a large number of artefacts from a single site have opened up a number of avenues which are simply not visible when only a small number of artefacts can be provenanced. In this paper, after evaluating the efficacy of our pXRF protocol for the provenancing of large numbers of obsidian artefacts, we go on to use the data set we generated from Kenan Tepe, in SE Turkey, to discuss the wide range of sources present including the hitherto poorly understood Group 3d. Our integrated study of the techno-morphological and contextual aspects of the artefacts alongside the provenance analysis also allows us to track the use of obsidian through time and to profile the use of individual sources.
\end{abstract}

\section{Highlights}

- Attribution of 882 obsidian artefacts from late prehistoric/early historic Kenan Tepe, south east Turkey to their geological sources.

- Analysis of change through time in the use of obsidian sources at a single site.

- Importance of contextual analysis of obsidian use.

- The first large scale occurrence of the unlocated Group 3d obsidian.

\section{Key words}

Obsidian, Resource acquisition, Turkey, North Mesopotamia, Ubaid, Late Chalcolithic, Early Bronze Age, Group 3d, High rubidium

\section{Introduction}

Interpretations of obsidian distribution have become synonymous with networking and exchange in the Middle East (Watkins 2003; Asouti 2006; Ortega et al. 2014; Ibáñez et al. 2015) and even considered as an example of a lingua franca in prehistoric times (Wansborough 1996). However, these studies have often drawn attention to the way in which the wider distribution network functioned as a whole rather than the choices that individual settlements, and even households within these communities, had to make between alternative potential sources of raw material. The lack of attention to these choices at a site-level has been amplified by the fact that only a small proportion of the artefacts from each site have been provenanced. It is only recently that exceptions have started to emerge, such as Çatalhöyük in Central Anatolia and Tell Aswad and Qdeir 1 in Syria where comprehensive analyses using laboratory based instruments has afforded a highly nuanced picture of obsidian use in central Anatolia (Carter et al. 2005; 2006; Carter and Shackley 2007; Poupeau et al. 2010) and extended our understanding of the use of eastern sources (Orange et al. 2013). Now that non-destructive analysis and portable instruments are readily 
available, opportunities for analysing large numbers of obsidian artefacts from a single site have become much more practical. Our analysis focuses on 882 late prehistoric and early historic artefacts (about $39 \%$ of the total assemblage) from Kenan Tepe in SE Turkey. We seek to investigate the range of sources of obsidian that were exploited at the site and to understand how choices between multiple sources were made.

Before interpreting the dataset generated by our analysis we review the use of portable energy dispersive X-ray fluorescence (pXRF) as a method for distinguishing between sources with particular reference to those in eastern Anatolia and establish the validity of our own methodology. Once established we are able to show how the comprehensive analysis of so many artefacts, both in terms of their geologic origin and also of their techno-morphological and contextual status, can help us to track the use of different sources through time in some detail. We can also demonstrate that a much wider range of sources that hitherto envisaged were also used, including the poorly understood $3 \mathrm{~d}$ source which we are now able to profile with confidence.

\subsection{The site of Kenan Tepe}

Kenan Tepe is located within the area to be flooded by the Ilısu dam on a limestone outcrop on the north bank of the Tigris River, approximately $15 \mathrm{~km}$ west of the TigrisBatman confluence in the Diyarbakir province, SE Turkey (Figure 1). The mound is relatively large being over $30 \mathrm{~m}$ high and about 4.5ha in extent. Excavations over 6 seasons between 2000 and 2007, directed by Bradley Parker as part of the Upper Tigris Archaeological Research Project (UTARP), revealed occupation dating from the Ubaid Period to the Middle Bronze Age followed by a small settlement in the early Iron Age (see Parker et al. 2006; 2009; Parker forthcoming).

Ubaid activity seems to be limited to the eastern and southern slopes of the high mound (Area D and E2) (Fig. 2) and probably originally covered an area of c.1ha (Parker et al. 2008, 3, 30; Parker et al. 2009). Four phases dating between c.4600-4400 BC have been identified (Parker and Kennedy 2010, 13,16). This is followed by Late Chalcolithic (c.3600-3100 BC) and Early Bronze Age (EBA; c.3100-2500 BC) activity at the east end of the lower town and on the slopes the high mound. The Middle Bronze Age (MBA) remains of a well-built stone structure have been found on the eastern, western and northern slopes of the high mound, dated to around $1800 \mathrm{BC}$ and partly overlying the Ubaid occupation in Trench D4.

Chert forms the predominant raw material for tool manufacture and was probably procured from the local river terraces. The main retouched forms are glossed blades, piercers and scrapers. Obsidian accounts for up to a quarter of the raw material used although the proportion fluctuates depending on context (Table 1). The majority come from the Ubaid levels where there is a substantial obsidian component (almost $25 \%$ of all chipped stone or just over 1700 artefacts) (Healey forthcoming). In this paper we discuss the provenancing of some 882 obsidian artefacts, which is about $39 \%$ of the entire obsidian assemblage and is a sample that had previously been selected for detailed technological study in Manchester. The obsidian assemblage is flake based with blades forming only a small proportion of the assemblage. Modified pieces included splintered pieces, side-blow blade flakes and edge retouched pieces, some of which are heavily worn. Apart from two arrowheads formal tools are rare (Healey forthcoming). Eighteen artefacts from Ubaid contexts had already been analysed in 
2012 using EMPA and one by pXRF (Frahm forthcoming). This showed that obsidian from five sources was present, although the sample size was insufficient to understand the full profile of the assemblage over time.

\begin{tabular}{lrrrr|rr}
\hline & Flint & Obsidian & \multicolumn{1}{c}{ Total } & $\begin{array}{c}\text { Percentage } \\
\text { obsidian }\end{array}$ & $\begin{array}{c}\text { Number } \\
\text { Analysed }\end{array}$ & $\begin{array}{c}\text { Percentage } \\
\text { Analysed }\end{array}$ \\
\hline Ubaid & 5303 & 1741 & 7044 & $24.7 \%$ & 509 & $29.2 \%$ \\
Late Chalcolithic* & 661 & 134 & 795 & $16.9 \%$ & 119 & $88.8 \%$ \\
EBA* & & 21 & & & 21 & $100.0 \%$ \\
MBA* & 78 & 89 & & & 89 & $100.0 \%$ \\
& & & & & 150 & $59.8 \%$ \\
\hline Uncertain/unstratified* & 791 & 251 & 1042 & $24.1 \%$ & 150 & $39.4 \%$ \\
\hline Total & 6833 & 2236 & 8881 & $25.2 \%$ & 882 \\
\hline the final analysis of the chipped stone assemblage from these contexts has not yet been untaken.
\end{tabular}

Table 1: The chipped stone assemblages from the main periods of occupation at Kenan Tepe, and amount of obsidian analysed.

\section{Methodology}

ED-XRF has a long history of use in archaeology and in the form of portable X-ray fluorescence analysis (pXRF) has been widely used in obsidian sourcing studies in recent years (Craig et al. 2007; Phillips and Speakman 2009; Nazaroff et al. 2010; Sheppard et al. 2010; Millhauser et al. 2011). It has been demonstrated that the method is capable of distinguishing between the major obsidian sources in the Middle East (Forster et al. 2011; Frahm 2013; Milić 2014; Frahm 2014a and 2014b). While pXRF instruments have gained frequent use in archaeology, both for analysis of obsidian and other materials, this has often been driven by accessibility, ease of use and cost. Although these are very significant advantages, there have been less rigorous attempts to optimise the analytical workflow or to gauge measurement uncertainty (Conrey et al. 2014; Speakman and Shackley 2013; Lynch et al. 2016).

In this study, analysis was performed using a Thermo Scientific Niton XL3t 980 GOLDD+. The instrument generates X-rays via a miniaturized $50 \mathrm{kV}, 200 \mu \mathrm{A}$ tube with a silver anode. The XL3t GOLDD+ analyser has a silicon drift detector (SDD), with a resolution better than $155 \mathrm{eV}$. This is similar to the model that has been successfully used for obsidian characterisation in the Middle East by Frahm (Frahm 2013 and 2014b; Frahm et al. 2014b) and the Aegean (Frahm et al. 2014a; Le Bourdonnec at al. 2013, 2015), although different instrument settings were employed in our study. All readings were taken using a Thermo Scientific mobile test stand.

Both the soil and the mining $(\mathrm{Cu} / \mathrm{Zn})$ modes of this instrument were evaluated before selecting a preferred protocol. The two modes differ in several details. The soil mode only uses three filters, while the mining mode also enables the light range filter, which allows analysis of elements where $Z<17$ without using a helium purge or vacuum pump. The soil mode relies on Compton normalization (CN) to convert raw X-ray counts to elemental concentrations. The mining mode uses fundamental parameters (FP) as a correction scheme. Although the initial readings produced by the soil and mining modes do differ, they are highly correlated and, after calibration (see section 2.1), the difference between them is minor. This is mirrored by Frahm's comparisons between the equivalent modes of an older model of the same instrument, in which he 
concluded that the soils mode with the default factory calibration had slightly greater accuracy but with "calibration, the difference among modes is minor for most elements, and the measurements become directly compatible with published data" (Frahm et al. 2014a, 250). We have used mining mode ( $\mathrm{Cu} / \mathrm{Zn}$ ) in our standard procedure because it allows us to take readings for light elements, and particularly for Al which can be useful for distinguishing between specific geological sources. The mining mode also produces significantly more precise readings for Ba (cf Frahm et al. 2014a, 236).

Reading times were determined after a series of replicate analyses using different settings, carried out using two internal obsidian standards, one a calc-alkaline obsidian from Göllüdağ and the other a peralkaline obsidian from Nemrut Dağ, selected so that a range of different elemental concentrations were represented. We aimed to minimise reading times while not compromising significantly on precision. Although it is tempting to select a conservative, longer reading time, there are several scenarios where time can be a significant constraint, including when the objective is to process a large quantity of archaeological material. Accuracy is not necessarily impacted by shorter reading times and the relationship between reading time and precision is nonlinear (Frahm et al. 2014b; Newlander et al. 2015). Newlander et al. (2015) have shown that, after empirically established inflection points, lengthening reading times does not markedly improve either reproducibility or accuracy. We repeatedly reran the same two internal standards to establish the point at which reproducibility declined significantly. As a result of this a standard approach was adopted which offers a satisfactory combination of high reproducibility and optimal through-put. A 90 second reading time has been used, composed of 20 seconds each using the main, low and high filters and 30 seconds using the light filter. With the addition of time taken to switch filters, the real-world time to take a reading is approximately 125 seconds, allowing up to 150-175 readings to be completed in a rather full working day. Where a greater throughput is desirable, this also gives us the option of omitting the light filter, which excludes $\mathrm{Al}$ and Si determinations but retains directly comparable results for all the other elements.

An important constraint on the measurement of archaeological material is the thickness of artefacts. Again a series of tests were run on different thicknesses of material, in this case carefully selected debitage from experimental knapping of a single large block of obsidian, which allowed us to select flat samples of known thickness where variability between the composition of the samples is likely to be very low. Again multiple readings were taken on each sample to control for instrument variability. Although thickness probably starts to have a small impact for some elements at less than c.8mm thickness, this seems to be well controlled by the internal calibration of the instrument until the thickness becomes less than $c .1 .7 \mathrm{~mm}$. This compares to previous studies with similar instruments which have suggested that measurements below 2mm become dubious (Davies et al. 2011; Orange et al. 2013; Le Bourdonnec et al. 2013). While usable readings can be feasible below this threshold (e.g. Frahm 2016), the impact varies depending on the discrimination between the specific sources. In this study, as we had the advantage of a very large sample in which the large bulk were of more substantial size, we excluded 29 samples with a thickness of less than $1.7 \mathrm{~mm}$ leaving 882 artefacts for analysis. While this reduces the assemblage slightly, it does reflect a more consistent, hand collected assemblage. 
Previous studies using pXRF instruments have suggested that the possibility that measurements can fluctuate over time or have a periodic fluctuation (Brand and Brand 2014). Potential long-term fluctuations have been monitored by including one or more international standards at the start and end of every session of measurements, with a compressed powder pellet of NIST-278 always included. Over a year, significant long-term variation has not been detected. Systematic fluctuations associated with instrument performance over shorter periods were tested by continuously running the instrument from cold with automatic replicate analyses of a compressed powder pellet of NIST-278 for a period of 14 hours. While this indicated that there is no systematic fluctuation in the instrument readings, it also demonstrated that, for light elements only, there is a significant warm-up time before readings stabilise (Figure 3 ). For most elements the manufacture's recommendation of a 5-minute instrument warm-up is sufficient. However, for Si and particularly for Al, a minimum warm-up period of 60 minutes is required to allow the readings to stabilise.

\subsection{Calibration}

The raw results from the instrument are already subject to built-in internal calibration. However, to provide data comparable to that obtained from other techniques as well as control for potential instrumental variation through time, a further calibration is required. For this we used a composite reference set of international standards and obsidian artefact samples to provide an obsidian-specific calibration. The former were analysed as compressed powder pellets and included NIST-278 (obsidian), BIR-1 (basalt), BCR-2 (basalt) and W-2a (diabase) amongst others. The obsidian artefact samples were thick with flat faces and had been previously analysed by major laboratories. Specifically, we used two sets of material, mainly from the site of Domuztepe, that had been analysed by laser ablation ICP-MS by Poidevin in the Clermont-Ferrand laboratory (using techniques documented in Poidevin 1998; Chabot et al. 2001) and using EPMA by Frahm (for technique see Frahm 2010). For a few elements ( $\mathrm{Al}, \mathrm{Ca}, \mathrm{Mn}$ and $\mathrm{Nb}$ ), our correlation with the international standards and the laser ablation ICP-MS group was markedly higher than with the group analysed by EPMA and the EPMA data for those elements was accordingly excluded from our calibration. Obviously where the EPMA analysis did not measure specific elements, these too were calibrated using only international standards and laser ablation ICP$\mathrm{MS}$ values ( $\mathrm{Rb}, \mathrm{Sr}$ and $\mathrm{Pb}$ ). This comparative data was used to create a custom calibration using a simple linear regression. For most elements there is a high degree of correlation between our calibrated, measured results and the external reference set, measured with a standard $r^{2}$ statistic (Table 2). For the most useful elements for classification of obsidian to source in the Middle East the correlation is above 0.97. Although it drops to 0.67 for $\mathrm{Al}$ and 0.78 for $\mathrm{Ba}$, the differences in compositions of different sources are of sufficient magnitude that, used with caution, these are still useful elements to analyse. 


\begin{tabular}{|l|r|}
\hline Element & $\mathrm{r}^{2}$ \\
\hline $\mathrm{Al}$ & 0.67 \\
$\mathrm{Si}$ & 0.81 \\
$\mathrm{~K}$ & 0.98 \\
$\mathrm{Ca}$ & 0.92 \\
$\mathrm{Ti}$ & 0.99 \\
$\mathrm{Mn}$ & 0.98 \\
$\mathrm{Fe}$ & 0.99 \\
$\mathrm{Zn}$ & 0.97 \\
$\mathrm{Rb}$ & 0.98 \\
$\mathrm{Sr}$ & 1.00 \\
$\mathrm{Zr}$ & 1.00 \\
$\mathrm{Nb}$ & 0.97 \\
$\mathrm{Ba}$ & 0.78 \\
$\mathrm{~Pb}$ & 1.00 \\
\hline
\end{tabular}

Table 2: $r^{2}$ values for correlation with the data set used for calibration to standards

\subsection{Analysis}

The artefacts from Kenan Tepe were first cleaned in an ultrasonic bath in distilled water for 15 minutes. Each artefact was analysed, using a standard 90 second reading as described above, on the flattest surface and at the thickest point. For most artefacts only a single reading was taken but periodic second readings were taken as a check for replicability. After the results were analysed, all artefacts that did not clearly fall within the primary sources groups for Kenan Tepe were routinely analysed again to ensure that their readings were consistent and not simply an anomaly. In total $11 \%$ of artefacts were read more than once, and some up to five times. In almost all cases the repeat readings confirmed the initial reading and a mean was used in subsequent analysis. The exceptions were a small number that initially had anomalously high values for Ti. Repeat readings and close inspection confirmed that these artefacts had been numbered with white ink that had not been completely removed. In these cases, the initial readings were discarded and the artefact cleaned again before re-reading them.

A further sample of 50 artefacts was reanalysed with the same instrument after it had had a routine factory recalibration. The reason was that the new factory calibration added $Y$ to the elements that could be recorded using the mining $(\mathrm{Cu} / \mathrm{Zn})$ mode. These readings were also recalibrated with a new custom calibration, based entirely on a wider set of international standards and with slightly higher $r^{2}$ correlations. Other procedures remained the same. The reanalysed sample was selected to represent the main groups present at Kenan Tepe and was mainly intended to allow us to profile the concentration of $Y$ in each compositional group. However, the values for all elements were consistent with the original analyses.

\section{Results}

To assign artefacts to sources, we referenced a set of analyses which had been carried out on source samples using the same pXRF instrument and the same analytical procedures, although each source specimen was analysed multiple times (usually 3) to produce a mean result with a lower error. Our source database includes 991 individual specimens from all the major geological sources in Anatolia and Armenia. Almost all are geological samples from precise locations, although in a small minority 
of cases we relied on duplicate readings on archaeological artefacts that had already been assigned to source by a major laboratory (again by laser ablation ICP-MS and EPMA) to more accurately represent the variability of the source material. Additional information was drawn from the much wider set of published analyses that have been conducted on geological source material at a wide range of laboratories and could be correlated with our data; in all analytical data was available for more than 2500 readings of geological obsidian.

\subsection{Kenan Tepe: source assignation}

The results will be discussed using bivariate plots for clarity but principal components analysis (PCA) was also carried out using the software JMP version 12 (SAS 2015), providing a multivariate analysis of the groupings and confirming the patterns noted in the bivariate plots. The bulk of the Kenan Tepe analyses can be readily assigned to distinct groups. Peralkaline obsidian can be distinguished on the basis of several elements, including high Fe and $\mathrm{Zr}$. These are considered separately in the following discussion. A simple plot of Sr to Zr (adopting a similar approach to Carter et al. 2013 and others) is helpful in providing an initial separation of the remaining sources Fig. 4).

\begin{tabular}{|l|rr|}
\hline \multicolumn{1}{|c|}{ Source } & Number & Percent \\
\hline Bingöl A & 122 & 13.83 \\
Bingöl B & 122 & 13.83 \\
Group 3d & 278 & 31.52 \\
Meydan Dağ & 5 & 0.57 \\
Muş & 2 & 0.23 \\
Nemrut Dağ & 339 & 38.44 \\
Nemrut/Bingöl A & 4 & 0.45 \\
Pasinler & 1 & 0.11 \\
Pokr Arteni & 5 & 0.57 \\
Sarıkamış 1 & 1 & 0.11 \\
Sarıkamış 2 & 1 & 0.11 \\
Syunik & 1 & 0.11 \\
Unknown & 1 & 0.11 \\
\hline Total & 882 & \\
\hline
\end{tabular}

Table 3: Proportion of obsidian from each source

In fig. 4, it can be seen that a major group (122 artefacts) matches samples known to be from the calc-alkaline Bingöl B source group. This is a tight match and is clearly separated from other potential sources, with Sr ranging from 39 and 53 ppm and Zr between 306 and 363 ppm. The association between source samples and artefacts remains consistent when other groups of elements or PCA were used. The data from the analysis of Bingöl B obsidian in many other studies confirms the chemical profile of this group (e.g. Carter et al. 2013; Cauvin et al. 1991; Poidevin 1998: 138).

The second general grouping (465 artefacts) is composed of peralkaline obsidian and is very distinct, with Sr below 4 ppm and Zr between 1084 and 1461 ppm. Two consistent sub-groups within these peralkaline obsidians are visible across several elements, with a few artefacts scattered between them. This is true using PCA and combinations of these elements in bivariate and 3D scatterplots (Fig. 5). In the past 
the two peralkaline sources, Nemrut Dağ and Bingöl A, have proved difficult to distinguish but recent analyses have regularly been able to reliably distinguish them using a range of element combinations and ratios (e.g. Frahm 2012; Orange et al. 2013; Carter et al. 2013). In the Kenan Tepe artefacts, the two groups correspond well with source material representing the two peralkaline sources Nemrut Dağ (339 artefacts) and Bingöl A (122 artefacts) apart from the small number (4) that fall between them where the exact peralkaline sub-source has to remain undetermined. While multiple sub-groups at Nemrut Dağ have been attested by a range of studies (Poidevin 1998; Frahm 2012; Orange et al. 2013), most have not been identified in archaeological contexts, perhaps due to being of insufficient quality for knapping and it now seems likely that most come from the Sicaksu source (Robin et al. 2015). In most archaeological studies (e.g. Frahm 2014a; Carter et al. 2013) where the two peralkaline sources have been distinguished, there is a simple division into two groups assignable to Nemrut Dağ and Bingöl A. We propose that this is also the case with the Kenan Tepe examples.

The third major group (278 artefacts), however, is more intriguing, especially as it makes up a large proportion of the total obsidian from Kenan Tepe. It is a tightly clustered set of readings and remains distinct across multiple combinations of elements and in PCA analysis, so there is little reason to doubt that it forms a single group and that it represents material from a single source. One of its distinguishing features is the high readings of $\mathrm{Rb}$ (a mean of $460 \pm 19.8 \mathrm{pmm}$, at $1 \mathrm{SD}$ ) and $\mathrm{Pb}$ (with a mean of $66 \pm 4.5 \mathrm{ppm}$ at $1 \mathrm{SD}$ ) which mark it out a being very distinct from any other Middle Eastern source (Fig. 6). It is also visually distinctive being opaque and usually black in colour, although some have reddish-brown streaks; it has a grainy texture, and often contains spherulites. Five of the artefacts from this group (kn-487, kn-488, kn-491, kn-498, kn-500) were analysed previously by Frahm, using EMPA (Frahm forthcoming), who assigned them to the Muş source(s). However, there are several reasons to suggest that the identification of the source is not that straightforward, and Frahm's EMPA analysis did not include Rb due to the quantity of Si (Frahm 2010, 372). We consider these artefacts to come from the elusive Group 3d, with its characteristically high level of Rb. Although this source has been known since the early work of Renfrew, Dixon and Cann $(1966 ; 1968)$, it has never been possible to assign it to a physical source (Chataigner 1998) and it has only occurred rarely in subsequent analyses (as summarised in section 5.1). This is the first time such a large assemblage of this obsidian has been analysed and offers the opportunity to profile its characteristics.

The obsidian from Kenan Tepe that we identify as coming from Group 3d can also be distinguished from other sources using elements other than $\mathrm{Rb} . \mathrm{Pb}$ is consistently higher than recorded for other Middle Eastern sources, almost always above 55ppm. Even on a simple $\mathrm{Zr}$-Sr plot, Group 3d obsidian can be distinguished from Muş and Pasinler by the higher concentrations of $\mathrm{Sr}$ (Fig. 4). The concentration of $\mathrm{Nb}$ (used in combination with $Y$ to distinguish obsidian from Muş and Pasinler by Carter et al. 2013) is lower than Muş samples; the values for Fe are also consistently slightly higher for this major Kenan Tepe group than for geological specimens from Muş.

In addition, there are a small number of artefacts (17) of obsidian that originates elsewhere in eastern Turkey and Armenia. These include five artefacts that appear to originate from Meydan Dağ (kn-552, kn-554, kn-680, kn-868 and kn-880), five from Pokr Arteni (kn-100, kn-681, kn-750, kn-779 and kn-842), two from two different 
sources at Sarikamıș (kn-146 and kn-481, from the Handere/Hamamli and Mescitli/Sehitemin outcrops respectively, Chataigner and Gratuze 2014a), two from Muş (kn-141, kn-907), one from Pasinler (kn-485) and one that probably comes from Syunik (kn-743). A single artefact (kn-321) is currently harder to pin down. It is possible that it is an outlying value from Meydan Dağ but this seems unlikely; Kars Arpaçay is perhaps a more likely possibility. We are, at present, treating it as unassigned.

Our analysis thus confirms that the bulk of the obsidian used at Kenan Tepe comes from sources within c.150 km of the site in direct line distance, although the access routes were probably at least $250 \mathrm{~km}$ (Fig. 11). Nemrut Dağ is the dominant source with the Bingöl A and Bingöl B obsidian present in roughly equal proportions from sources that, although geochemically distinct, are geographically within c. $30 \mathrm{~km}$ of each other. Together they account for about the same amount of obsidian as that from Nemrut Dağ. The location of the Group 3d source is unknown but there is a strong probability that it comes from the same general area (cf Chataigner 1998, 317). The presence of obsidian from far distant sources raises other questions which are also discussed in Section 5.

\section{Sources: through time and technology}

Emboldened by Carter's discussion of the way the obsidian from different sources was used at Körtik Tepe (Carter et al. 2013), we move beyond simply documenting the presence of obsidian from different sources at Kenan Tepe and briefly consider the chronological and techno-typological aspects of the assemblage, although this forms part of a more in depth study and will be published elsewhere.

\subsection{Fluctuation in source use through time}

The vast proportion of obsidian comes from Ubaid contexts, but it also has a continued presence in later periods. Four sources dominate throughout the occupation, but as can be seen in Fig. 8 the relative proportion of each source varies through time. Obsidian from Nemrut Dağ accounts for just over a third of the obsidian in the Ubaid period and increases in importance over time as does that from Bingöl A (except in the Middle Bronze Age). On the other hand, Bingöl B declines in popularity as a source through time and is completely absent from the Early Bronze Age contexts, although this could be a factor of the limited sample from this phase. Obsidian of Group $3 d$ is at its peak in the Ubaid, drops off in the Chalcolithic but has a resurgence in the Middle Bronze Age.

\begin{tabular}{|c|c|c|c|c|c|c|c|c|c|}
\hline \multirow[b]{2}{*}{ Source } & \multicolumn{2}{|l|}{ Ubaid } & \multicolumn{2}{|c|}{ Late Chalcolithic } & \multicolumn{2}{|l|}{ EBA } & \multicolumn{2}{|l|}{ MBA } & \multirow[b]{2}{*}{ Total } \\
\hline & Number & $\%$ & Number & $\%$ & Number & $\%$ & Number & $\%$ & \\
\hline Nemrut Dağ & 180 & 35.4 & 49 & 41.2 & 15 & 71.4 & 33 & 37.1 & 277 \\
\hline Bingöl A & 70 & 13.8 & 23 & 19.3 & 5 & 23.8 & 13 & 14.6 & 111 \\
\hline Nemrut/Bingöl A & 2 & 0.4 & & & & & & & 2 \\
\hline Bingöl B & 85 & 16.6 & 16 & 13.4 & & & 8 & 9.0 & 109 \\
\hline Group 3d & 162 & 31.8 & 28 & 23.5 & 1 & 4.8 & 34 & 38.2 & 225 \\
\hline Other & 10 & 1.7 & 3 & 2.5 & & & 1 & 1.1 & 14 \\
\hline Total & 509 & & 119 & & 21 & & 89 & & 738 \\
\hline
\end{tabular}

Table 4: Proportion of provenance obsidian from each source in the major periods at Kenan Tepe (144 artefacts from poorly stratified contexts excluded).

These general patterns mask some very localised variations in the 200 years of Ubaid activity (see Parker et al. 2009 for a description of the Ubaid settlement). Most of this obsidian comes from Ubaid phase 1 contexts where there is an outdoor working area 
and little evidence of domestic activity. Obsidian from Nemrut Dağ dominates in this phase with Bingöl A and Bingöl B obsidian reaching 17 and 23\% respectively and Group $3 d$ insignificant. Obsidian from Muș, Arteni and Sarıkamıș are also present. In phases 2 and 3 where a large structure with associated storage areas was excavated there is much less obsidian. The majority of the obsidian comes from Nemrut Dağ but with significant amounts from the Bingöl A and B sources. Group 3d obsidian has a minor role as earlier. In Ubaid phase 4, although a smaller area was excavated, things seem to change; there is an increase in the amount of obsidian present much of which comes from single trench (E2). We also see a reversal of the fortunes of Nemrut Dağ obsidian compared to those of Group 3d which accounts for almost $70 \%$ of the obsidian. This may result from the reduction of a few cobbles in specific knapping episodes as discussed in section 4.2).

\begin{tabular}{|c|c|c|c|c|c|c|c|c|c|c|c|c|c|}
\hline & \begin{tabular}{|l|} 
Unphased \\
Ubaid
\end{tabular} & $\%$ & $\begin{array}{l}\text { Ubaid } \\
\text { mixed }\end{array}$ & $\%$ & \begin{tabular}{|l|}
$\begin{array}{l}\text { Ubaid } 1 \\
\text { all }\end{array}$ \\
\end{tabular} & $\%$ & Ubaid 2 & $\%$ & \begin{tabular}{|l|}
$\begin{array}{l}\text { Ubaid } 3 \\
\text { all }\end{array}$ \\
\end{tabular} & $\%$ & \begin{tabular}{|l|}
$\begin{array}{l}\text { Ubaid } 4 \\
\text { all }\end{array}$ \\
\end{tabular} & $\%$ & Total \\
\hline Unknown & & & & & & & & & & & 1 & 0.8 & 1 \\
\hline Bingöl A & 13 & 13.9 & 4 & 16.6 & 34 & 17.8 & 2 & 9.5 & 10 & 16.6 & 7 & 5.9 & 70 \\
\hline Bingöl B & 12 & 12.6 & 3 & 12.5 & 45 & 23.5 & 2 & 9.5 & 16 & 26.6 & 7 & 5.9 & 85 \\
\hline Group 3d & 34 & 35.8 & 10 & 41.6 & 25 & 13.1 & 2 & 9.5 & 8 & 13.3 & 83 & 69.7 & 162 \\
\hline Meydan Dağ & & & & & 0 & & & & & & & & 0 \\
\hline Muş & & & & & 2 & 1.0 & & & & & & & 2 \\
\hline Nemrut Dağ & 33 & 34.7 & 6 & 25 & 82 & 42.9 & 15 & 71.4 & 25 & 41.6 & 19 & 16.1 & 180 \\
\hline Nemrut/Bingöl A & & & & & 1 & 0.5 & & & 1 & 1.6 & & & 2 \\
\hline Pasinler & & & 1 & 4.2 & & & & & & & & & 1 \\
\hline Pokr Arteni & 3 & 3.2 & & & 1 & 0.5 & & & & & & & 3 \\
\hline Sarıkamış 1 & & & & & 1 & 0.5 & & & & & & & 2 \\
\hline Sarıkamış 2 & & & & & & & & & & & 1 & 0.8 & 1 \\
\hline Syunik & & & & & & & & & & & & & 0 \\
\hline Total & 95 & & 24 & & 191 & & 21 & & 60 & & 118 & & 509 \\
\hline
\end{tabular}

Table 5: Proportion of each source in each Ubaid phase at Kenan Tepe

Some of the fluctuations may be due to the size of the sample present and/or analysed. Nevertheless, we note that this is not a steady change through time but seems to fluctuate between phases and even within the individual Ubaid phases. This suggests that there is not a simple explanation of changing supply zones or a move to place more emphasis on efficient access routes. Indeed, it seems likely that it is wrong to see this purely in terms of a diachronic explanation. It is worth emphasising the nature of the archaeological sample from which our obsidian is drawn. The material comes from a spatially scattered of trenches dug at various locations across the site (Fig. 2). Although a wide range of time periods have been sampled by the excavations, this sample is not unbiased. In none of the time periods do we have a sample that allows us to evaluate the obsidian acquisition strategies of the sites as a whole. Instead, we have access to a series of sub-samples, each of which may reflect a unique social, functional or temporal context. What we have analysed and presented as samples through time are really samples of the discard activities from various subcommunities or specific activities within the wider settlement. While they may reflect long-term patterns, they are more likely to represent variability between different sub-communities, whether these are based on different households, different functions or very short-term chronological shifts.

We would suggest, therefore, that the variation we see between periods, within the Ubaid in particular, reflects the fact that this essentially represents a sampling of different sub-communities, through deep time certainly but also across groups which may have had access to different networks of supply and impacted by short-term events that impacted on obsidian supply. 


\subsection{Variations in the techno-morphology of the artefacts}

In order to have a more solid basis for interpreting acquisition strategies it is useful to consider the techno-morphological characteristics of the provenanced artefacts from Kenan Tepe on a source-by-source basis. At this stage in our analysis, it is not broken down by chronological period. This will be discussed in detail in another publication (and see also Healey forthcoming for a description of the entire Ubaid assemblage) and only a preliminary summary is given here.

In general, there is an overwhelming impression of an expedient, flake-based assemblage. Between $29 \%$ and $36 \%$ of Nemrut Dağ and Bingöl obsidians, and as high as $65 \%$ of Group 3d (and more if the retouched examples are included) are flakes; blades constitute less than $18 \%$. Judging by the characteristics of the proximal ends of the flakes they were likely produced by direct percussion. Together with cores, chunks and chips and core-maintenance pieces that were recovered it is probable that some core reduction took place within the village of Kenan Tepe. By way of contrast few of the blades are complete and no true blade cores were recovered and it may be that blades were acquired as blades rather than being produced in the village; most if not all, are typical of blades produced by pressure flaking.

Nemrut Dağ obsidian is both predominant and produced the widest range of artefacts types. There are at least four blade segments with heavy wear, not unlike that seen on Çayönü tools, a rim fragment from a bowl (kn-0501) and two pieces with ground edges as well as flakes and blades with retouched edges.

Side-blow blade-flakes are present among the obsidian from Bingöl B, Bingöl A and Nemrut Dağ but are most frequent among the Nemrut Dağ obsidian (cf Nishikai 1996). Notably they do not occur among the Group 3d obsidian artefacts where blades are in any case rare.

Splintered pieces or pièces esquillées occur in all types of obsidian including the rarer types. Their purpose is enigmatic and may have been used for a variety of purposes (see for example Astruc 2011, Ibáñez et al. 2008; Conolly 2003, 367); alternatively, they may represent the final stages in the life of intensively worked pressure flaked cores which involved bipolar percussive flaking as at Çatalhöyük (Carter and Milić 2013, 429, Fig 21.9) and which may be the case for the Group 3d splintered pieces at Kenan Tepe.

Artefacts of Group 3d obsidian show a completely different profile from those from Nemrut Dağ and Bingöl. Apart from being the dominant type of obsidian used in Ubaid phase 4, the Group 3d obsidian concentrated in trench E2 may suggests specific knapping episodes. There is, for example, an elevated amount of obsidian in the micro-debris for some contexts in trench E2 (Loci 164, 168, 169 and 126) (Parker et al. 2009, 99-100; graph 2) and, though the obsidian from the micro-debris itself has not yet been provenanced, is most likely to result from the reduction of the Group $3 \mathrm{~d}$ obsidian as there is no other numerically significant obsidian among the provenanced material from the trench. Amongst the provenanced artefacts, there are five cores and a number of chunks; flakes (including those with retouch) form $71 \%$ of assemblage and a weathered outer surface or "cortex" is present on about $37 \%$ of the flakes. Aside from a number of splintered pieces and the flakes with edge retouch, there is little evidence of modification. 
Physically, the Group 3d obsidian from Kenan Tepe is very distinctive. It seems to occur in the form of smallish pebbles (estimated from flakes which have cortex at both ends and on their sides to have had a maximum dimension of 10-15 mm) with a scored and battered cortex (Fig 7); cortex is present on over a third of the pieces (104/278) which contrasts sharply with artefacts other sources where pieces with cortex are rare. The obsidian is opaque and mostly black in colour, although there are some pieces which are a reddy-brown colour and some have red streaks (Figure 7). It has a slightly grainy texture and tends to contain spherulites and much of that found at Kenan Tepe is not of particularly good flaking quality, though this may not necessarily be a universal property (Campbell and Healey in prep.).

\begin{tabular}{|c|c|c|c|c|c|c|c|c|c|c|c|}
\hline & \multicolumn{4}{|c|}{ Debitage } & \multicolumn{6}{|c|}{ Modified } & \\
\hline & 凹 & $\begin{array}{l}\frac{\mathscr{U}}{\pi} \\
\frac{\pi}{L}\end{array}$ & $\begin{array}{l}\frac{\tilde{d}}{0} \\
\frac{\tilde{0}}{\omega}\end{array}$ & 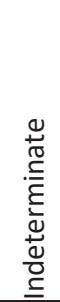 & 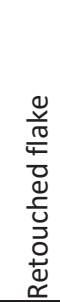 & $\begin{array}{l}0 \\
0 \\
\frac{0}{0} \\
0 \\
0 \\
0 \\
\frac{0}{0} \\
0 \\
0 \\
0 \\
\alpha\end{array}$ & 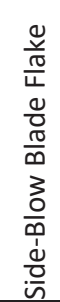 & 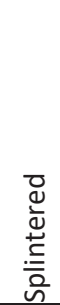 & $\begin{array}{l}\bar{\Phi} \\
\stackrel{ \pm}{0}\end{array}$ & 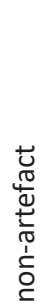 & 要 \\
\hline Bingöl A & 1 & 45 & 22 & 15 & 5 & $22^{1}$ & 7 & 5 & & & 122 \\
\hline Bingöl B & & 40 & 18 & 13 & 6 & 29 & 6 & 10 & & & 122 \\
\hline Group 3d & 8 & 204 & 14 & 20 & & 6 & & 26 & & & 278 \\
\hline $\begin{array}{l}\text { Meydan } \\
\text { Dağ }\end{array}$ & & 2 & 1 & 1 & & & & 1 & & & 5 \\
\hline Muş & & & & 1 & 1 & & & & & & 2 \\
\hline Nemrut Dağ & & 101 & 58 & 28 & 4 & $79^{2}$ & 32 & 33 & $3^{3}$ & 1 & 339 \\
\hline $\begin{array}{l}\text { Nemrut } \\
\text { Dağ/Bingöl } \\
\text { A }\end{array}$ & & 2 & 1 & 1 & & & & & & & 4 \\
\hline Pasinler & & & & & & & & 1 & & & 1 \\
\hline Pokr Arteni & & 1 & 2 & & & 1 & & 1 & & & 5 \\
\hline Sarıkamış 1 & & & 1 & & & & & & & & 1 \\
\hline Sarıkamış 2 & & & & & & 1 & & & & & 1 \\
\hline Syunik & & & 1 & & & & & & & & 1 \\
\hline Unknown & & 1 & & & & & & & & & 1 \\
\hline Total & 6 & 374 & 117 & 85 & 33 & 133 & 45 & 80 & 3 & 1 & 882 \\
\hline
\end{tabular}

Table 6: Typological composition of the provenanced assemblage by source (all periods)

Obsidians from other, very distant, sources form only a minute proportion of the total assemblage and seem to have been incorporated into the tool kit as flakes and blades, some of which are retouched or are splintered pieces and do not seem to have been treated as anything special.

\section{Multiple Choices: the acquisition of obsidian at Kenan Tepe}

The integrated large-scale analysis and provenancing of the obsidian at Kenan Tepe allow us to explore possible modes of acquisition from a more secure database than has been possible up to now. 
A number of other things can influence why and from which source(s) the obsidian was chosen and for what purpose; these include need, proximity of site to source (journey time), accessibility of and the abundance and quality of the obsidian at a particular source and so on (cf Chataigner and Barge 2008) as well as less tangible factors such as prevailing social and political affiliations, potential networks and intermediaries and perhaps even personal preferences. Some of these factors might have been quite short term as the breakdown of obsidian use in the Ubaid period suggests (Fig. 8).

\subsection{Possible modes of acquisition of obsidian at Kenan Tepe}

The people at Kenan Tepe had a wide range of obsidian sources that were potentially available to them (Fig. 1) but seem to have preferred three of these. The acquisition strategy is not entirely clear. One possibility is direct access. Accessibility was certainly a key factor. We have already noted that most of the obsidian, regardless of period, provenanced from Kenan Tepe comes from sources about $135 \mathrm{~km}$ north (Bingöl A and Bingöl B) and $150 \mathrm{~km}$ north east (Nemrut Dağ) of the settlement, although the overland journey distance to each of these sources would be in the region of $250 \mathrm{~km}$, based on a least cost path analysis (Fig. 11). The regions in which these sources lie are about $150 \mathrm{~km}$ from each other. From the birds-eye perspective of the modern map it is tempting to suggest that these sources could be visited as a round trip via the Muș plain, which provides a relatively direct east-west connection between them, perhaps as part of an annual cycle of movement of herders through the landscape. While, to our eyes such a collection method might appear to make sense in terms of time and energy, the logic is probably flawed. Not only do pre-modern societies often evaluate optimisation strategies very differently but a narrow energy optimisation would favour obsidian from the last source visited which we do not see in the proportion of obsidian present from each source at Kenan Tepe, where Bingöl B and Bingöl A obsidian together constitute roughly the same amount as that from Nemrut Dağ. We might also note that obsidian from the Muș sources, which lie between the peralkaline sources of Bingöl and Nemrut Dağ, was hardly exploited at all. This may suggest the different sources represent different and perhaps independent axes of acquisition. The apparent decline of obsidian from the Bingöl complex over time may suggest this. In such a scenario, it may not simply have been accessibility that influenced choice but the extent to which accessibility meshed with other social and economic factors that controlled movement and determined how the landscape was exploited.

The other major component of the obsidian assemblage at Kenan Tepe is Group 3d, and it appears to have been acquired as raw nodules and reduced at site unlike the Nemrut and Bingöl obsidian. The location of the source of Group 3d obsidian has proved elusive. Chataigner suggested a general location in the region of Lake Van or perhaps a little to the west, based on the discovery of Group 3d obsidian together with obsidian from Bingöl, Nemrut Dağ and Meydan Dağ (1998, 317; Chabot et al. 2001). The evidence from Kenan Tepe confirms the association with Bingöl and Nemrut Dağ obsidian, but we would suggest that Group 3d should be sought in the region between Bingöl and Nemrut Dağ. There is nothing at Kenan Tepe to suggest that obsidian further east than Nemrut Dağ was exploited significantly. More specifically, unless there were deeper symbolic meanings, the source of Group 3d obsidian may have been more accessible to Kenan Tepe than either Bingöl and Nemrut Dağ simply because the obsidian is of markedly lower knapping quality and so one might expect that less energy would have been expended in its acquisition. Indeed, 
there is evidence elsewhere that such sources tend to be by-passed (Chataigner and Gratuze 2014b, 60). It is plausible that the Group 3d obsidian was particularly used when trips to the Bingöl and Nemrut Dağ regions were impractical, due to time of year, difficult social relations with communities along the routes or the absence of other reasons to visit those localities (for example, movement of herders). These circumstances might be quite short-term, leading to the sort of fluctuation seen in the use of Group 3d obsidian in Ubaid 4 at Kenan Tepe.

In many ways, the general region of Muş seems a plausible locality for Group 3d obsidian. Obsidian in this location remains relatively poorly studied (Chataigner et al. 2014) and the possibility of a substantial obsidian flow/outcrop which is as yet unsampled is not impossible. Furthermore, apart from the high $\mathrm{Rb}$ and $\mathrm{Pb}$ values, there are general similarities in the composition of Group 3d obsidian and obsidian from the Muș/Pasinler complex. Importantly, the access routes from Kenan Tepe are very different from those to the Bingöl or Nemrut Dağ regions making this region a plausible alternative supply.

Access to Nemrut Dağ and the Bingöl area, along with access to a putative Group $3 d$ area somewhere between them, might have been embedded as part of regular movements along routes in the landscape. Such movements are attested historically in this region for herders (cf Frahm and Feinberg 2013, 1131-2) and the distances are comparable to those travelled by transhumant pastoralists recorded at Gozedzor by Chataigner and Barge (2008). Alternatively obsidian acquisition may also have been managed through as yet undiscovered intermediate communities that were sufficiently close to Kenan Tepe that they always were likely to have had some degree of interaction with that settlement. We should also remember though that obsidian from these sources is found widely throughout the Middle East (Chataigner 1998) and this might suggest a more organised or even overarching distribution network may have existed at some periods. Even if the mechanisms of access to the three main regions from which the obsidian at Kenan Tepe was obtained was similar there are likely to have been nuances. For example, if obsidian was acquired through intermediate communities they may have been different for each source area and if access were direct it would have been through different route-ways.

All of these sources were suppliers for the site at all times during its occupation. However, the fluctuation in proportion of obsidian from each of them suggests that not all members of the community need have had equal access to them. Different households might have had different sets of social relations and access to different networks in the surrounding landscape. They might have participated in different patterns of movement across the landscape, perhaps dependent on their participation in subsistence activities or their access to ancestral pastures. There may have been short periods where access to an individual source was disrupted, for example when short-term conflict may have cut a route or disrupted friendly interaction with a key intermediate community, or even seasonally when snow would have made access to specific sources impossible. These fine distinctions between different households and the impact of short periods of disruption will only show up when archaeological deposits are examined on a fine chronological scale and with a large-scale sample.

A very different situation clearly pertains for the more distant sources of obsidian. These make up an economically insignificant proportion of the Kenan Tepe assemblage but provide significant insights into wider cultural connections. Obsidian 
from Meydan Dağ (or Gürgürbaba, Freund et al. 2012), some 120 km east of Nemrut Dağ, makes a token presence at Kenan Tepe in the form of a few flakes. Like the Nemrut and Bingöl obsidian, it is also widely diffused into Mesopotamia (Freund et al. 2012) and as far as Hagoshrim in the southern the Levant (Delerue 2007) from the late Neolithic onwards and was clearly a cosmopolitan source and it is perhaps surprising that there is so little of this obsidian at Kenan Tepe.

Our present knowledge of the north east Anatolian obsidians (the sources of which are located some $350 \mathrm{~km}$ or more north of Kenan Tepe) suggests that they were mainly exploited by local communities (Brennan 2000; Chataigner et al. 2014) although we are increasingly being able to document their occasional use further afield. As well as at Kenan Tepe they are found Tell Kurdu (Delerue 2007), Domuztepe (Frahm et al. 2016) and again at Hagoshrim in Israel (Delerue 2007; Schechter et al. 2013).

On the other hand, the main sources in Armenia (including Arteni, Gutansar and Syunik), east of the Araz and Akhurian rivers that approximate to the modern boundary with Turkey, only appear very sporadically in wider Mesopotamia, including at Domuztepe, although they are extensively exploited by communities more locally (Badalyan et al. 2004; Chatainger and Barge 2008).

This all leads us to suggest that there are a number of different modes of acquisition in operation at Kenan Tepe. Group 3d obsidian (fig. 9) was most likely acquired by direct access, perhaps by specific groups on limited occasions, demonstrated for example, in excavated contexts dating to the later part of the Ubaid occupation (Fig. 8). Nemrut Dağ and Bingöl obsidians (fig. 10) could have been obtained by direct or indirect (e.g. via herders or intermediate communities) access to sources along separate route ways. However, because of the wide spread use of these sources across northern Mesopotamia as a whole it may be that they were more controlled. In the case of the more distant obsidians, it may be more than coincidence that they also occur together at other sites in northern Mesopotamia and the Levant. This may be just a quirk of analysis or may suggest pathways that have not yet been identified. More likely they were obtained or handed on through casual exchanges but the indirect connections are themselves important. More and larger scale analyses may help to clarify this picture.

\section{Conclusions}

There are a number of advantages that the size of the sample from Kenan Tepe has allowed us to exploit. It has provided a fine-grained profile of how obsidian use changed through time and space at Kenan Tepe, and in particular pushes us to focus not on generalising temporal trends but on the sub-communities and activities that have produced particular sets of samples. More work remains to be done in this area, and will be published separately, but the breakdown in Table 6 already demonstrates marked differences in the way obsidian was used through time, and probably also in space within the site. This matches a move to a much more subtle, contextualised understanding of obsidian procurement and meaning within communities that is only possible with very large sample sizes (Maeda 2009; Carter et al. 2013). 
The size of the data set also allows us a better understanding of how far distant and rarely used sources should be understood. Certainly, it seems clear that the larger the data set analysed from Kenan Tepe, the greater the number of sources present. We analysed 882 obsidian artefacts and steadily increased the number of known sources as we analysed more samples; the artefact made from the single example of obsidian from Syunik in Armenia was the $742^{\text {nd }}$ artefact analysed and the last new source added to the list. We would expect additional, although very rare, examples would continue to be identified if we extended the analysis even further. While obsidian from these additional sources is very marginal in economic importance, profiling the range of sources is important for our understanding of the way in which a much wider obsidian network may have extended at different times.

The large-scale analysis contrasts with the classically small sample of obsidian from Kenan Tepe that was undertaken some years before the present study (Frahm forthcoming). That sample consisted of 18 artefacts, selected by Healey to give a profile of the assemblage. It identified Nemrut Dağ, Bingöl A and Bingöl B as important sources of obsidian. Muş was also identified as a significant source. This is now known to be Group 3d, which cannot be distinguished by EPMA for the reasons discussed above. However, there was also one artefact of obsidian from Pasinler, an identification confirmed in the present study, but we now know that this was the single example of this source in the entire analysed assemblage. Small number of artefacts can provide useful profiles of obsidian use, but they can easily be distorted by sampling bias, unintentional or accidental, and cannot pick up the subtleties of obsidian consumption.

The investment of time in processing a sample of this size is substantial. However, pXRF offers a reliable, rapid and economic method of analysis that is not limited to a laboratory but can be carried out in a museum or in the field. The primary analysis of the Kenan Tepe obsidian took just over a week of actual laboratory time. What becomes much more significant is, in fact, the additional time to record, photograph and analyse this scale of assemblage. However, the results show that such expenditure is rewarded by a much more nuanced understanding of the way in which an individual settlement exploited the potential of multiple choices of source materials.

\section{Acknowledgements}

Thanks are due to Professor Bradley Parker, University of Utah for providing the obsidian artefacts from Kenan Tepe. Diyarbekir Mușeum and Turkey's Ministry of Culture and Tourism kindly permitted analysis of the obsidian assemblage. Some of the background support for the early stages of the project came from a British Academy Small Research Grant. Our source reference set has been greatly enhanced by the provision of geo-referenced samples from a number of colleagues, in particular Akihiko Mochizuk, Osamu Maeda and Kristine Martirosyan-Olshansky. F.-X. Le Bourdonnec provided us with a wide range of geological aliquots which had also been analysed by other methods. We are very grateful to them and pleased to acknowledge their support. Osamu Maeda also read an earlier draft of this paper and discussed some of the ideas here with us. We are grateful to him and much appreciate his suggestions. Two anonymous referees provided valuable comments that have improved this article. The equipment and other facilities have been provided by the University of Manchester. 


\section{Table Captions}

Table 1: The chipped stone assemblages from the main periods of occupation at Kenan Tepe, and amount of obsidian analysed.

Table 2: $r^{2}$ values for correlation with the data set used for calibration to international standards

Table 3: Proportion of obsidian from each source

Table 4: Proportion of obsidian from each source in the major periods at Kenan Tepe (there are additionally 144 artefacts from poorly stratified sources)

Table 5: Proportion of each source in each Ubaid phase at Kenan Tepe

Table 6: Typological composition of the assemblage by source

\section{Figure Captions}

Figure 1: Location map, showing Kenan Tepe and the major obsidian sources in Anatolia and Armenia.

Figure 2: Topographic plan of Kenan Tepe, with the excavated areas that provided the obsidian samples (based on plan provided by Bradley Parker).

Figure 3: Repeat readings for Al with a 90 second measurement time.

Figure 4: Sr-Zr diagram, omitting peralkaline obsidian, showing the general distinction of sources.

Figure 5: 3D scatter plot, showing distinction between the Nemrut Dağ and Bingöl A peralkaline obsidian artefacts.

Figure 6: $\mathrm{Rb}-\mathrm{Pb}$ diagram, showing the clear distinction of Group 3d artefacts.

Figure 7: Proportion of main sources in the major periods at Kenan Tepe

Figure 8: Proportion of each source in the different sub-phases of the Ubaid.

Figure 9: Examples of obsidian artefacts from the Group 3d source. 1. kn-059; 2. kn207; 3. kn-772; 4. kn-315; 5. kn-306; 6. kn-398.

Figure 10: Examples of obsidian artefacts from other sources. Nemrut Dağ: 1. kn038; 2. kn-188; 3. kn-212. Bingöl B: 4. kn-039. 5. kn-056. Pokr Arteni: 6. kn-100; 7. kn779; Pasinler: 8. kn-141. Sarıkamış 9: kn-146. Meydan Dağ: 10. kn-554

Figure 11: Least cost pathways for the major obsidian sources at Kenan Tepe. Muş is not a major source but the route is indicated as a possible access direction for Group 3d obsidian. 


\section{Supplementary material}

Supplementary Table 1: Data

Supplementary Table 2: Details of the artefacts analysed

\section{Bibliography}

Asouti, E., 2006. Beyond the pre-pottery Neolithic B interaction sphere. Journal of World Prehistory 20(2-4), 87-126. Stable URL:

http://www.jstor.org/stable/25801246

Astruc, L., 2011. Du Gollü dağ à Shillourokambos : de l'utilisation d'obsidiennes anatoliennes en contexte insulaire. In: Guilaine, J., Briois, F., Vigne, J.D. (Eds.), Shillourokambos, un établissement néolithique pré-céramique à Chypre. Les fouilles du secteur 1. Ed. Errance. EfA. pp. 696-614.

Badalyan, R., Chataigner, C., Kohl, P., 2004. Trans-Caucasian obsidian: the exploitation of the sources and their distribution. In: Sagona, A. (Ed.) A View from the Highlands: Archaeological Studies in Honour of Charles Burney. Ancient Near East Studies Supplement 12, Leuven: Peeters. pp. 437-464.

Brand, N. W., Brand, C.J., 2014. Performance comparison of portable XRF instruments. Geochemistry: Exploration, Environment, Analysis 14(2), 125-138. doi:10.1144/geochem2012-172.

Brennan, P., 2000. Obsidian from volcanic sequences and recent alluvial deposits, Erzurum district, north-eastern Anatolia: chemical characterisation and archaeological implications. Ancient Near Eastern Studies 37, 128-152.

Carter, T., Poupeau, G., Bressy, C., Pearce, N.J.G. 2005. From chemistry to consumption: towards a history of obsidian use at Çatalhöyük through a programme of inter-laboratory trace-elemental characterization. In: Hodder, I. (Ed.), Changing Materialities at Çatalhöyük: Reports from the 1995-99 Seasons, McDonald Institute Monographs. McDonald Institute for Archaeological Research, pp. 285-305.

Carter, T., Poupeau, G., Bressy, C., Pearce, N.J.G., 2006. A new programme of obsidian characterization at Çatalhöyük, Turkey. Journal of Archaeological Science 33(7), 893-909. doi:10.1016/j.jas.2005.10.023

Carter, T., Shackley, M.S., 2007. Sourcing obsidian from Neolithic Çatalhöyük (Turkey) using energy dispersive X-ray fluoresence. Archaeometry 49(3), 437-454. doi: 10.1111/j.1475-4754.2007.00313.x

Carter, T., Grant, S., Kartal, M., Coşkun, A., Özkaya, V., 2013. Networks and Neolithisation: sourcing obsidian from Körtik Tepe (SE Anatolia). Journal of Archaeological Science 40, 556-569. doi:10.1016/j.jas.2012.08.003

Cauvin, M.-C., Besnus, Y., Tripier, J., Montigny, R., 1991. Nouvelles analyses d'obsidiennes du Proche-Orient: Modèle de géochimie des magmas ultilisé pour la recherché archéologique. Paléorient 17(2), 5-20. 
Chabot, J., Poidevin, J.L., Chataigner, C., Fortin, M., 2001. Caractérisation et provenance des artefacts en obsidienne de Tell'Atij et de Tell Gudeda (III' millénaire, Syrie). Cahiers d'Archeologie Du CELAT 10, pp. 241-254.

Chataigner, C., 1998. Sources des artefacts du Proche Orient d'après leur caractérisation géochimique. In: Cauvin, M.-C., Gourgaud, A., Gratuze, B., Arnaud, N., Poupeau, G., Poidevin, J.-L., Chataigner, C. (Eds.), L'obsidienne au Proche et Moyen Orient. Du volcan à l'outil, British Archaeological Reports International Series 738, pp. 273-324.

Chataigner, C., Barge, O., 2008. Quantitative approach to the diffusion of obsidian in the ancient northern Near East. In: Posluschny, A., Lambers K., Herzog I. (Eds.), Layers of Perception. Proceedings of the 35th International Conference on Computer Applications and Quantitative Methods in Archaeology (CAA). Bonn, Rudolf Habelt GmbH, pp. 1-7.

Chataigner, C., and Gratuze, B., 2014a. New data on the exploitation of obsidian in the southern Caucasus (Armenia, Georgia) and eastern Turkey, Part 1: Source characterization. Archaeometry 56(1), 25-47. doi:10.1111/arcm.12006.

Chataigner, C, and Gratuze, B., 2014b. New data on the exploitation of obsidian in the southern Caucasus (Armenia, Georgia) and eastern Turkey, Part 2: Obsidian procurement from the Upper Palaeolithic to the Late Bronze Age. Archaeometry 56(1), 48-69. doi: 10.1111/arcm.12007.

Chataigner, C., Ișikli, M., Gratuze, B., Çil, V., 2014. Obsidian sources in the regions of Erzurum and Kars (north-east Turkey): New data. Archaeometry 56(3): 351-374. doi: 10.1111/arcm.12002

Conrey, R. M., Goodman-Elgar, M., Bettencourt, N., Seyfarth, A., Van Hoose, A., Wolff, J. A., 2014. Portable X-ray fluorescence spectrometer calibration for archaeological samples using influence coefficients. Geochemistry Exploration Environment Analysis 14. 291-301. doi: 10.1144/geochem2013-198.

Craig, N., Speakman, R. J., Popelka-Filcoff, R. S., Glascock, M. D., Robertson, J. D., Shackley, M. S., Aldenderfer, M. S., 2007. Comparison of XRF and PXRF for analysis of archaeological obsidian from southern Perú, Journal of Archaeological Science 34(12), 2012-2024. doi:10.1016/j.jas.2007.01.015

Davis, M. K., Jackson, T. L., Shackley, M. S., Teague, T., Hampel, J., 2011. Factors affecting the Energy-Dispersive X-Ray Fluorescence (EDXRF) analysis of archaeological obsidian. In: Shackley, M.S. (Ed.) X-Ray Fluorescence Spectrometry (XRF) in Geoarchaeology, Springer Publishing, New York, pp. 45-64. .

Delerue, S., 2007. L'obsidienne dans le processus de néolithisation du Proche-Orient (12000-6500 BC). PhD thesis. Université Michel de Montaigne, Bordeaux 3. Pessac.

Forster, N., Grave, P., Vickery, N., Kealhofer, L., 2011. Non-destructive analysis using PXRF: methodology and application to archaeological ceramics. X-ray Spectrometry 40(5), 389-398. doi: 10.1002/xrs.1360 
Frahm, E., 2010. The Bronze-age Obsidian Industry at Tell Mozan (Ancient Urkesh), Syria. PhD thesis. Department of Anthropology, University of Minnesota. Available online at University of Minnesota's Digital Conservancy: http://purl.umn.edu/99753.

Frahm, E., 2012. Distinguishing Nemrut Dağ and Bingöl A obsidians: geochemical and landscape differences and the archaeological implications. Journal of Archaeological Science 39 (95), 1436-1444. doi:10.1016/j.jas.2012.06.038

Frahm, E., 2013. Validity of "off-the-shelf" handheld portable XRF for sourcing Near Eastern obsidian chip debris. Journal of Archaeological Science 40 (2), 1080-1092. doi:10.1016/j.jas.2012.06.038

Frahm, E. 2014a. Buying local or ancient outsourcing? Locating production of prismatic obsidian blades in Bronze-Age northern Mesopotamia. Journal of Archaeological Science 41, 605-621. doi:10.1016/j.jas.2013.10.007

Frahm, E. 2014b. Characterizing obsidian sources with portable XRF: Accuracy, reproducibility, and field relationships in a case study from Armenia. Journal of Archaeological Science 49, 105-125. doi:10.1016/j.jas.2013.10.007

Frahm, E., 2016. Can I get chips with that? Sourcing small obsidian artifacts down to microdebitage scales with portable XRF Journal of Archaeological Science: Reports 9, 448-467. doi.org/10.1016/j.jasrep.2016.08.032

Frahm, E., forthcoming in Healey, E. The Lithic Artifacts from the Ubaid Period Contexts at Kenan Tepe with a Contribution on the Obsidian Raw Material Sources (Section 6.4) in Parker, B.J. (ed.), forthcoming, The Upper Tigris Archaeological Research Project: The Ubaid Period at Kenan Tepe, Cotsen Institute of Archaeology Press, Los Angeles.

Frahm, E., Feinberg, J. M., 2013. Empires and resources: Central Anatolian obsidian at Urkesh (Tell Mozan, Syria) during the Akkadian period. Journal of Archaeological Science 40(2), 1122-1135. doi:10.1016/j.jas.2013.10.007

Frahm, E., Doonan, R.C.P., Kilikoglou, V., 2014a. Handheld portable X-ray fluorescence of Aegean obsidians. Archaeometry 56(2), 228-260. doi: 10.1111/arcm.12012

Frahm, E., Schmidt, B. A., Gasparyan, B., Yeritsyan, B., Karapetian, S. Meliksetian ,K., Adler, D. S., 2014b. Ten seconds in the field: rapid Armenian obsidian sourcing with portable XRF to inform excavations and surveys. Journal of Archaeological Science 41, 333-348. doi:10.1016/j.jas.2013.10.007

Frahm, E., Campbell, S., Healey, E., 2016 Caucasus Connections? New Data and Interpretations for Armenian Obsidian in Northern Mesopotamia. Journal of Archaeological Science: Reports 9, 543-564. doi.org/10.1016/j.jasrep.2016.08.023

Freund, K., Carter, T., Contreras, D. A., Açlan, M., Köse, O., 2012. The Character and Use of the Gürgürbaba Tepe (Meydan Dağ) Obsidian Source (Turkey). Annual Meeting of the American Schools of Oriental Research, Chicago - November 14th$18^{\text {th }}, 2012$. (poster) 
Healey, E., forthcoming. The lithic artifacts from the Ubaid period contexts at Kenan Tepe. In: Parker, B. J. (ed.) The Upper Tigris Archaeological Research Project: The Ubaid Period at Kenan Tepe, Cotsen Institute of Archaeology Press, Los Angeles.

Hole, F., 2000. The prehistory of the Khabur. In: Rouault, O., Wäfler, M. (Eds.), La Djéziré et l'Euphrate Syriens de la Protohistoire à la Fin du II Millénaire av. J.C.: Tendances dans I'Interprétation Historique des Données Nouvelles, Brepols, Turnhout, pp. 17-28.

Ibáñez, J.J., González Urquijo, J.E., Rodriguez Rodriguez, A.A., 2008. Analyse fonctionelle de l'outillage lithique de Mureyet. In: Ibáñez, J.J. (Ed.), Le site néolithique de Tell Mureybet (Syrie du Nord): en hommage à Jacques Cauvin. British Archaeological Reports International Series, 1843, pp. 363-406.

Ibáñez, J.J., Ortega, D., Campos, D., Khalidi, L., Méndez, V., 2015. Testing complex networks of interaction at the onset of the Near Eastern Neolithic using modelling of obsidian exchange. Journal of the Royal Society Interface 12, 20150210. doi:10.1098/rsif.2015.0210.

Le Bourdonnec, F.-X., Bellot-Gurlet, L., Dillmann, P., Poupeau, G., Lugliè, C., BressyLeandri, C., 2013. P-XRF: quelles limites pour les études de provenance d'obsidienne en Méditerranée occidentale? In: XIXe Colloque du GMPCA, 238.

Le Bourdonnec, F.X., Bellot-Gurlet, L., Luglié, C., Bressy-Leandri, C. 2015. Archéométrie de l'obsidienne: déchiffrer la circulation d'une matière première. Les nouvelles de l'archéologie 138. doi:10.4000/nda.2722

Lynch, S., Locock, A. J., Duke, M. J. M., Weber, A. W., 2016. Evaluating the applicability of portable-XRF for the characterization of Hokkaido Obsidian sources: a comparison with INAA, ICP-MS and EPMA. J. Radioanal. Nucl. Chem. doi 10.1007/s10967-016-4766-9.

Maeda, O., 2009. The materiality of obsidian and the practice of obsidian use in the Neolithic Near East. PhD thesis. University of Manchester.

Milić, M., 2014. PXRF characterisation of obsidian from central Anatolia, the Aegean and central Europe. Journal of Archaeological Science 41, 285-296.

doi:10.1016/j.jas.2013.08.002.

Millhauser, J. K., Fargher, L. F., Heredia Espinoza, V. Y., Blanton, R.E., 2015. The geopolitics of obsidian supply in Postclassic Tlaxcallan: A portable X-ray fluorescence study. Journal of Archaeological Science 58, 133-146. doi:10.1016/j.jas.2015.02.037

Nazaroff, A. J., Prufer, K. M., Drake, B. L., 2010. Assessing the applicability of portable $X$-ray fluorescence spectrometry for obsidian provenance research in the Maya lowlands. Journal of Archaeological Science 37(4), 885-895.

doi:10.1016/j.jas.2013.10.007 
Newlander, K., Goodale, N., Jones, G. T., Bailey, D. G., 2015. Empirical study of the effect of count time on the precision and accuracy of pXRF data. Journal of Archaeological Science: Reports 3, 534-548. doi:10.1016/j.jasrep.2015.07.007.

Orange, M., Le Bourdonnec, F.-X., Lugliè, C., Bellot-Gurlet, L., Dubernet, S., JoannesBoyau, R., Poupeau, G., Scheffers, A., 2014. Vers une détermination exhaustive de la provenance des obsidiennes en Méditerranée Occidentale: élaboration d'une stratégie analytique. Poster. RST PAU 204. 24e Réunion des Sciences de la Terre.

Orange, M., Carter, T., Le Bourdonnec, F.-X., 2013. Sourcing obsidian from Tell Aswad and Qdeir 1 (Syria) by SEM-EDS and EDXRF: Methodological implications. Comptes Rendus Palevol 12, 173-180. doi:10.1016/j.crpv.2012.11.001

Ortega, D., Ibañez, J.-J., Khalidi, L. ,Méndez, V., Campos, D., Teira, L., 2014. Towards a multi-agent-based modelling of obsidian exchange in the Neolithic Near East. Journal of Archaeological Method and Theory 21, 461-485. doi 10.1007/s10816-013-9196-1

Parker, B. J., Dodd, L., Creekmore, A., Healey, E., Painter. C., 2006. The Upper Tigris Archaeological Research Project (UTARP): A preliminary report from the 2003 and 2004 field seasons. Anatolica 32, 71-151.

Parker, B. J., Foster, C. P., Nicoll, K., Kennedy, J. R., Graham, P., Smith, A., Hopwood, D. E., Hopwood, M., Butler, K., Healey, E., Uzel, M. B., Jensen, R., 2009. The Upper Tigris Archaeological Research Project (UTARP): A preliminary report from the 2007 and 2008 field seasons at Kenan Tepe. Anatolica 35, 85-152.

Parker, B. J., Kennedy, J. R., 2010. A quantitative attribute analysis of the Ubaidperiod ceramic corpus from Kenan Tepe. Bulletin of the American Schools of Oriental Research 358, 1-26.

Parker, B. J. (ed.), forthcoming. The Upper Tigris Archaeological Research Project: The Ubaid Period at Kenan Tepe, Cotsen Institute of Archaeology Press, Los Angeles.

Phillips, S. C., Speakman, R. J., 2009. Initial source evaluation of archaeological obsidian from the Kuril Islands of the Russian Far East using portable XRF. Journal of Archaeological Science 36 (6), 1256-1263. doi:10.1016/j.jas.2009.01.014

Poidevin, J.-L., 1998. Les gisements d'obsidienne de Turquie et de Transcaucasie: géologie, gééochimie et chronométrie. In: Cauvin, M.-C., Gourgaud, A., Gratuze, B., Arnaud, N., Poupeau, G., Poidevin, J. L., Chataigner, C. (eds.), L'Obsidienne au Proche et Moyen Orient: Du volcan à l'outil. British Archaeological Reports International Series 738, pp. 105-204.

Poupeau, G., Le Bourdonnec, F.-X., Carter, T., Delerue, S., Shackley, M. S., Barrat, J.A., Dubernet, S., Moretto, P., Calligaro, T., Milić, M., Kobayashi, K., 2010. The use of SEM-EDS, PIXE and EDXRF for obsidian provenance studies in the Near East: a case study from Neolithic Çatalhöyük (central Anatolia). Journal of Archaeological Science 37(11), 2705-2720. doi:10.1016/j.jas.2010.06.007

Renfrew, C., Dixon, J. E., Cann, J. R., 1966. Obsidian and early cultural contact in the Near East, Proceedings of the Prehistoric Society 32, 30-72. 
Renfrew, C., Dixon, J. E., Cann, J. R., 1968. Further analysis of Near Eastern obsidians. Proceedings of the Prehistoric Society 34, 319-333.

Robin, A.-K., Mouralis, D., Kuzucuoğlu, Akköprü, E., Gratuze, B., Doğu. A. F., Erturaç, K., Cétoute, J., 2015. Les affleurements d'obsidiennes du Nemrut (Anatolie orientale): mise en évidence d'une source exploitable, premiers résultats. Géomorphologie 21(3), 217-234.

SAS 2015 JMP, Version 12.1. SAS Institute Inc., Cary, NC.

Schechter, H., Marder, O., Barkai, R., Getzov, N., Gopher, A., 2013. The obsidian assemblage from Neolithic Hagoshrim, Israel: pressure technology and cultural influence. In: Borrell, F., Ibáñez, J. J.,Molist, M., (Eds). Stone Tools in Transition: From Hunter-Gatherers to Farming Societies in the Near East. Bellaterra (Barcelona), Universitat Autònoma de Barcelona. Servei de Publicacions, pp. 509-528.

Shackley, M. S. (Ed.), 2011. X-Ray Fluorescence Spectrometry (XRF) in Geoarchaeology. New York, Springer. doi:10.1007/978-1-4419-6886-9

Sheppard, P., Trichereau, B., Milicich, C., 2010. Pacific obsidian sourcing by portable XRF, Archaeology in Oceania 45(1), 21-30. Stable URL: http://www.jstor.org/stable/20743942

Speakman, R. J., Shackley, M. S., 2013. Silo science and portable XRF in archaeology: a response to Frahm. Journal of Archaeological Science 40(2), 1435-1443.

doi:10.1016/j.jas.2012.09.033

Wansbrough, J. E., 1996. Lingua franca in the Mediterranean. Curzon Press, Richmond.

Watkins, T., 2008. Supra-regional networks in the Neolithic of southwest Asia. Journal of World Prehistory 21(2), 139-171. Stable URL:

http://www.jstor.org/stable/25801256 


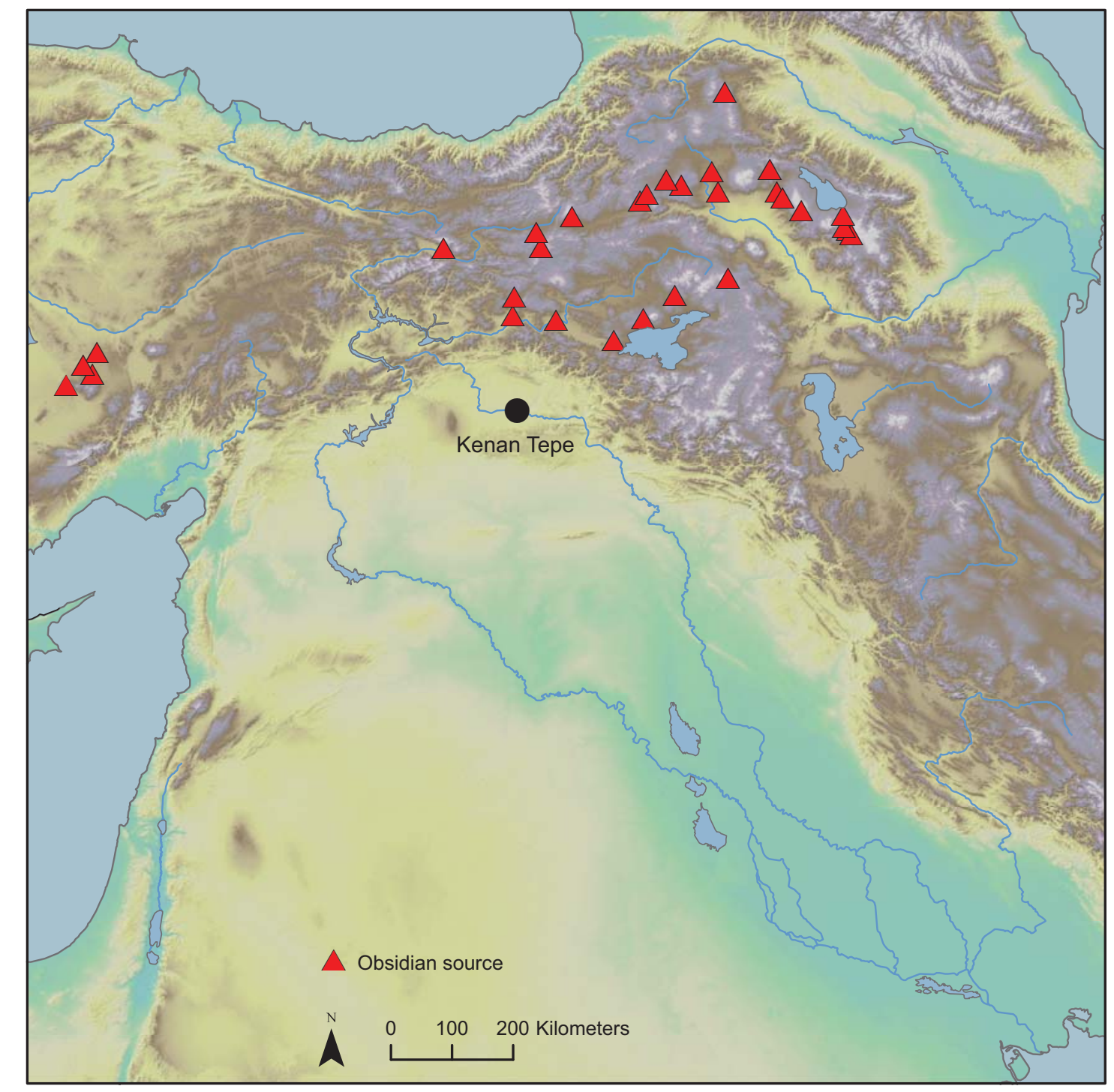

Fig. 1 


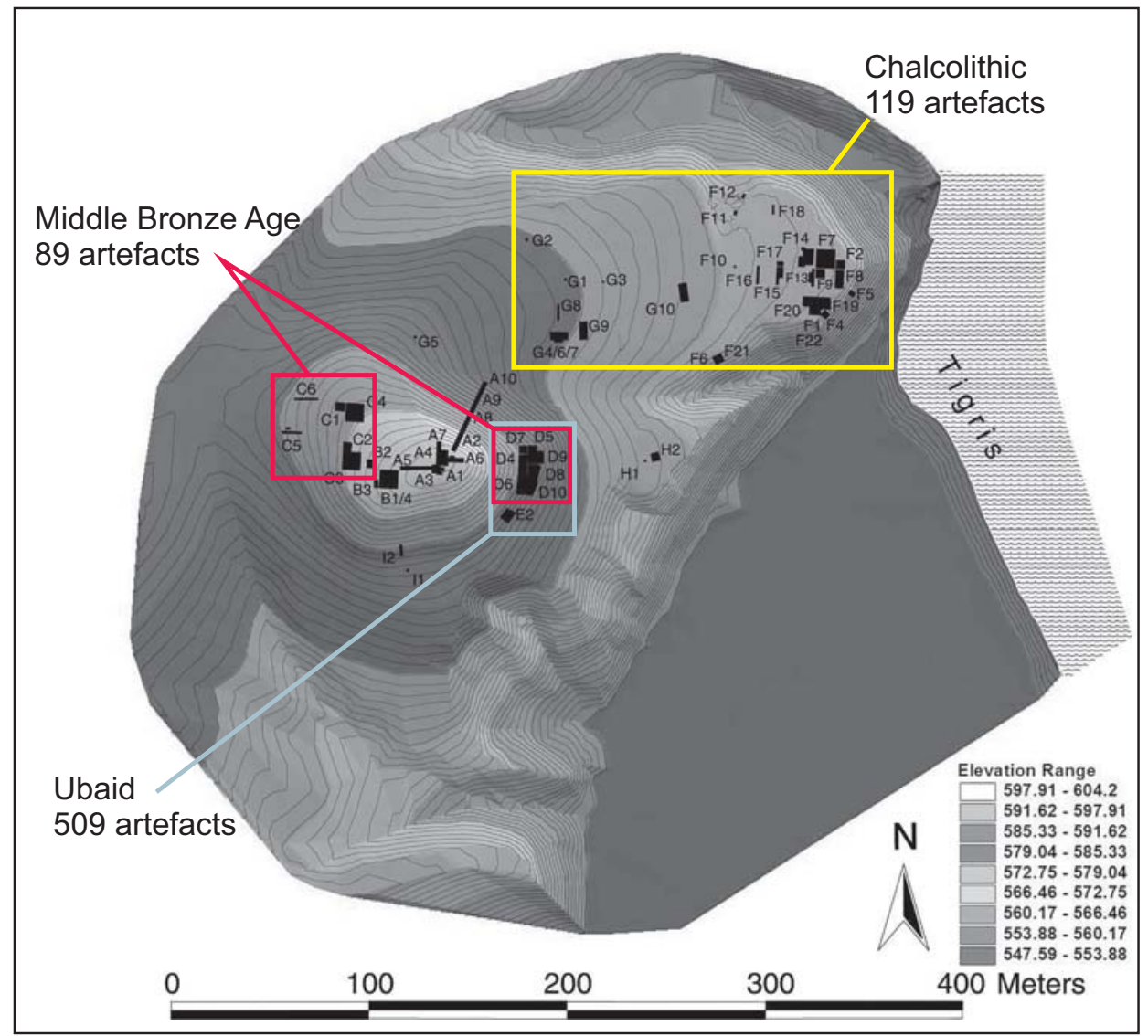

Fig. 2 


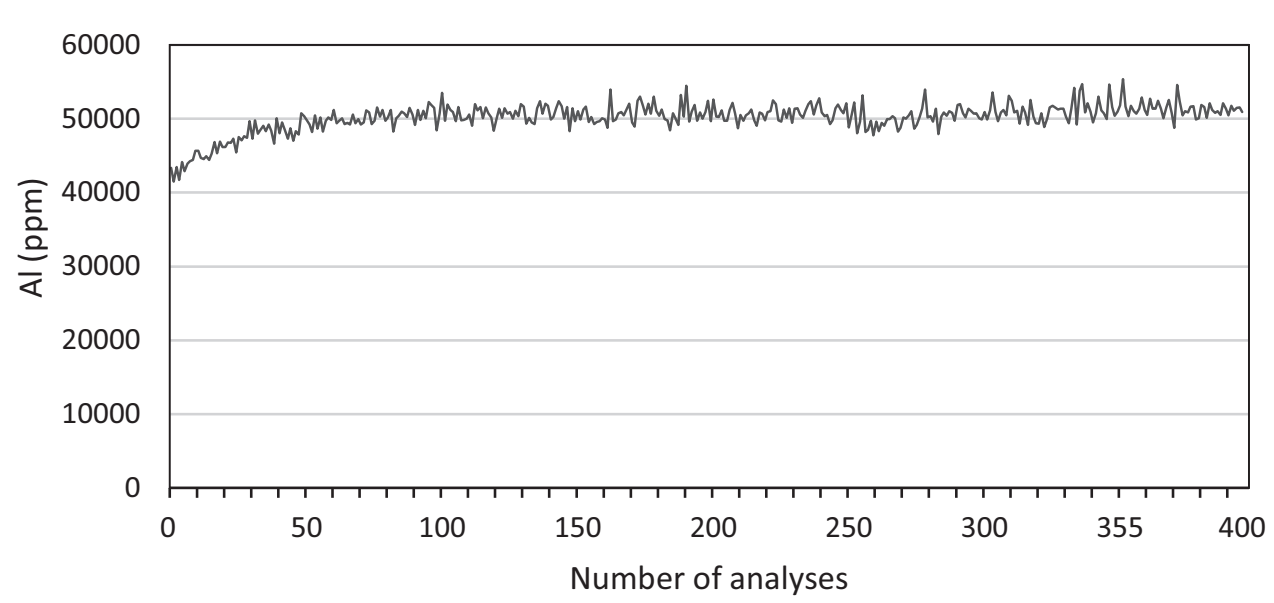

Fig. 3 


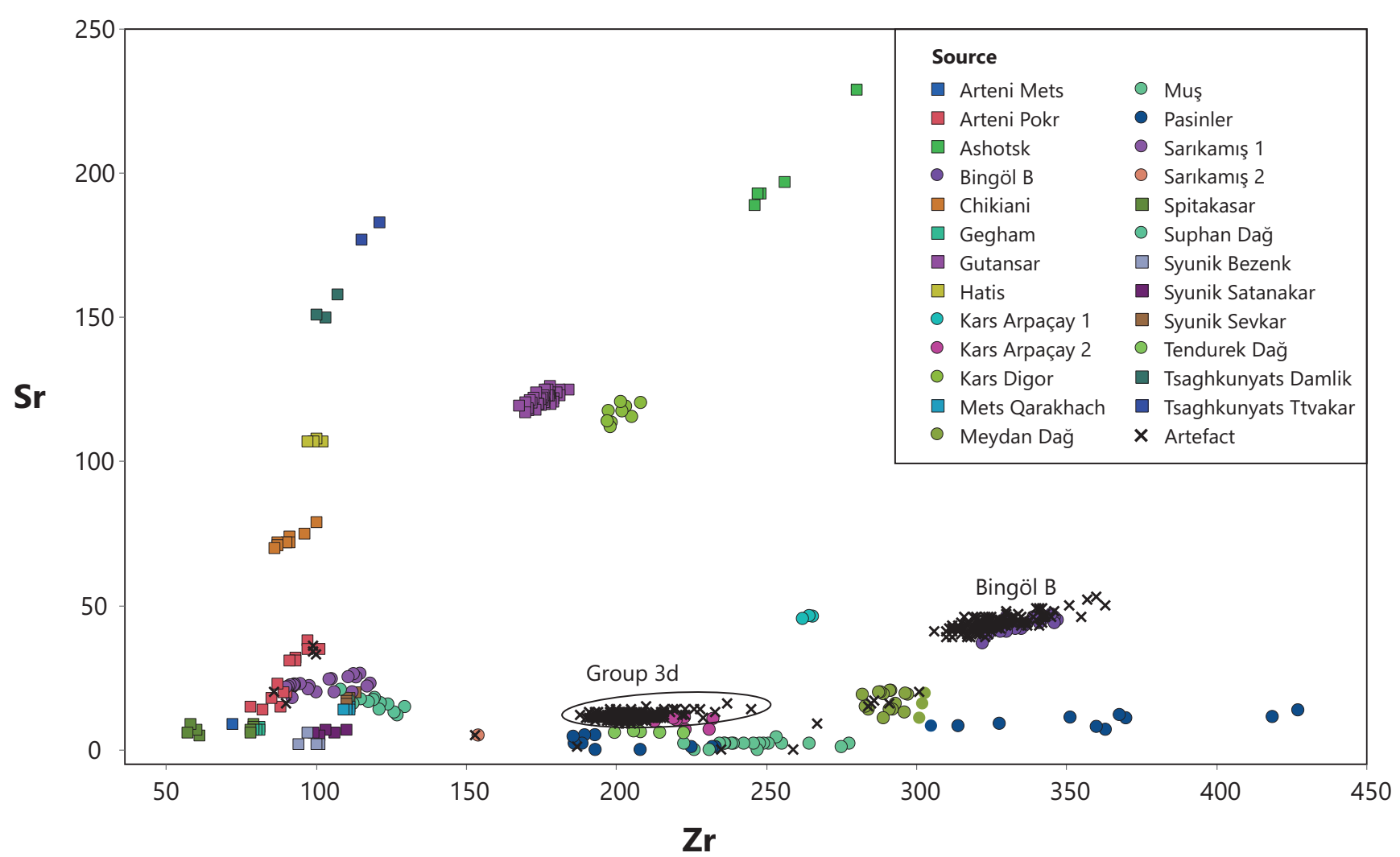

Fig. 4 


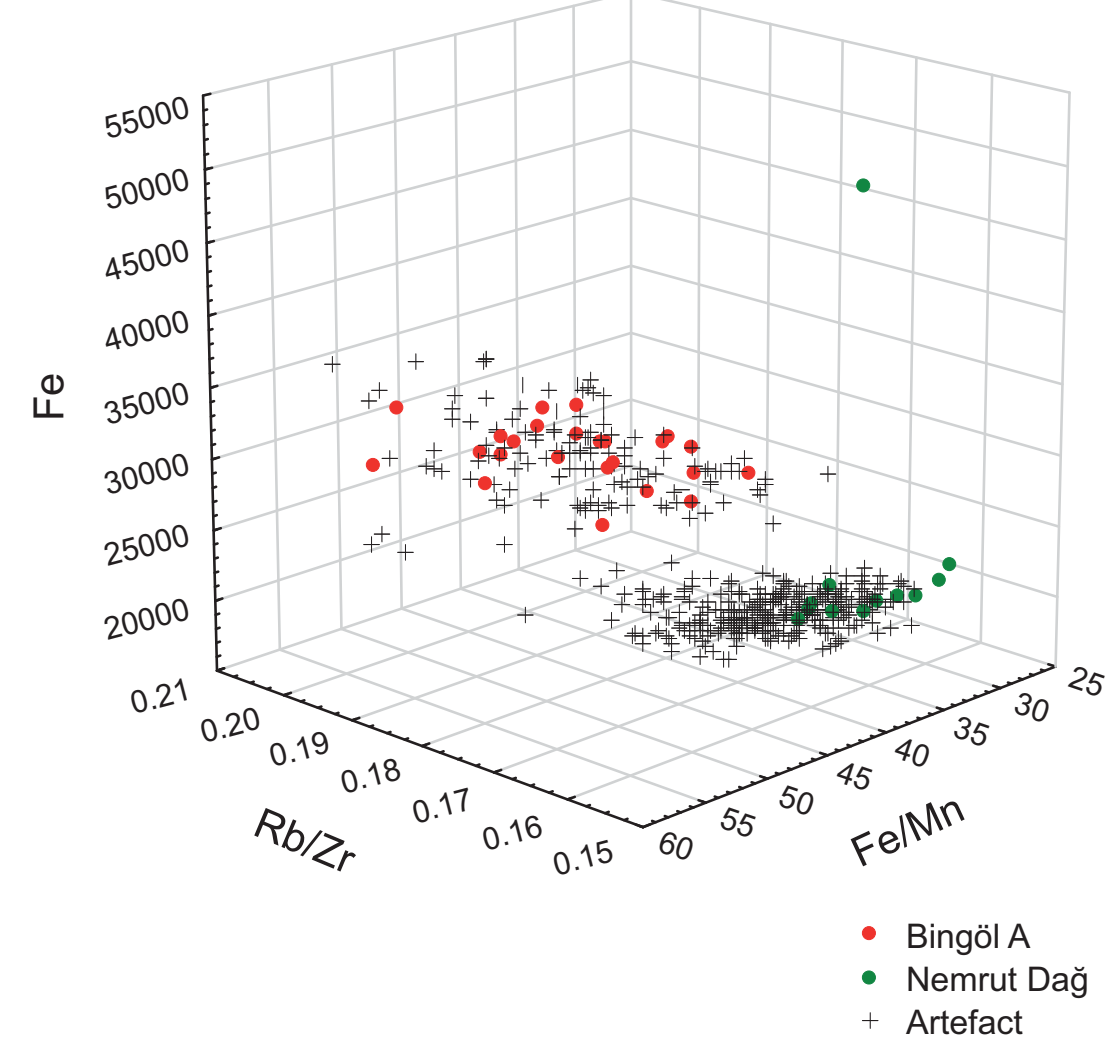

Fig. 5 


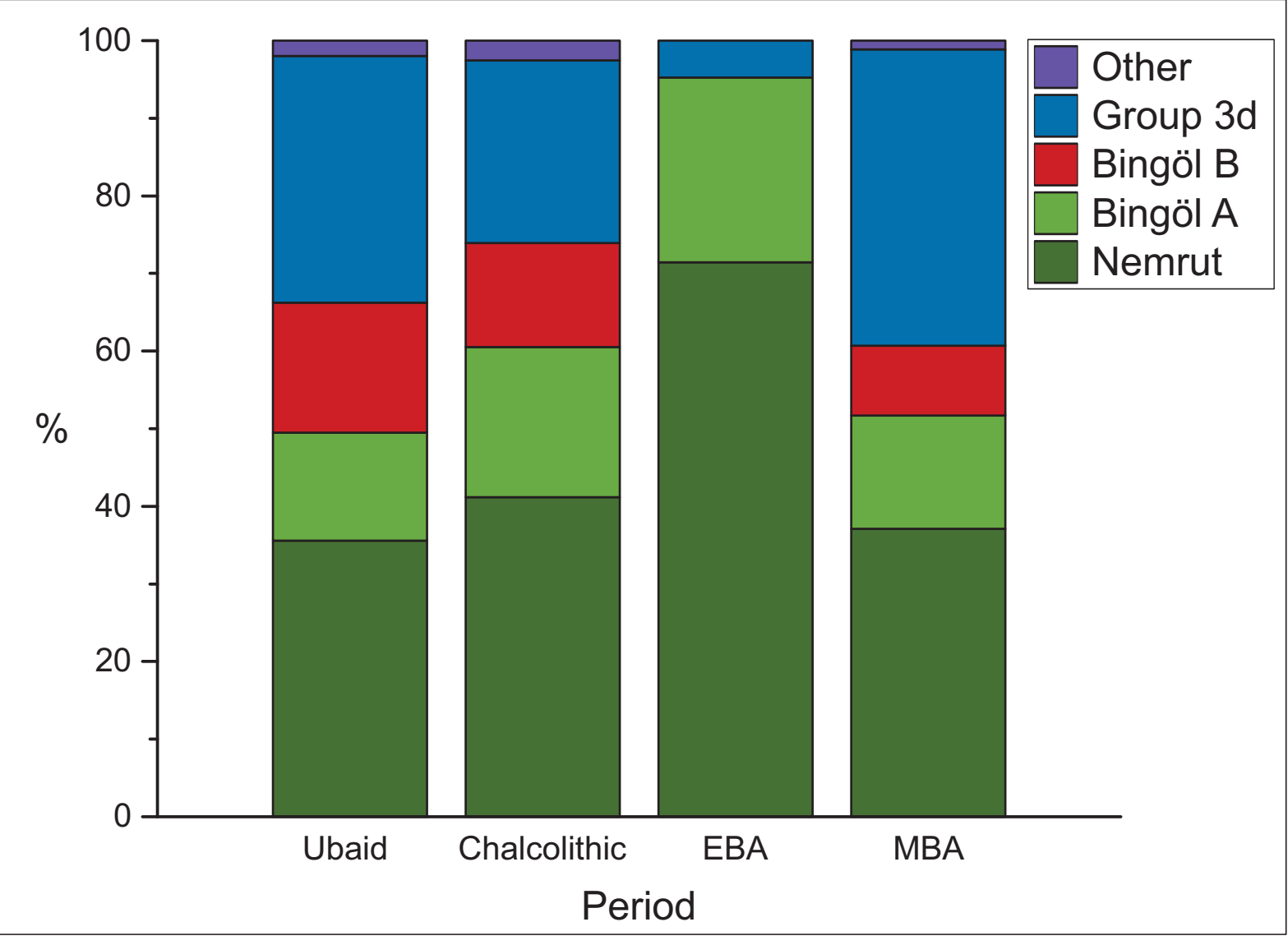

Fig. 7 


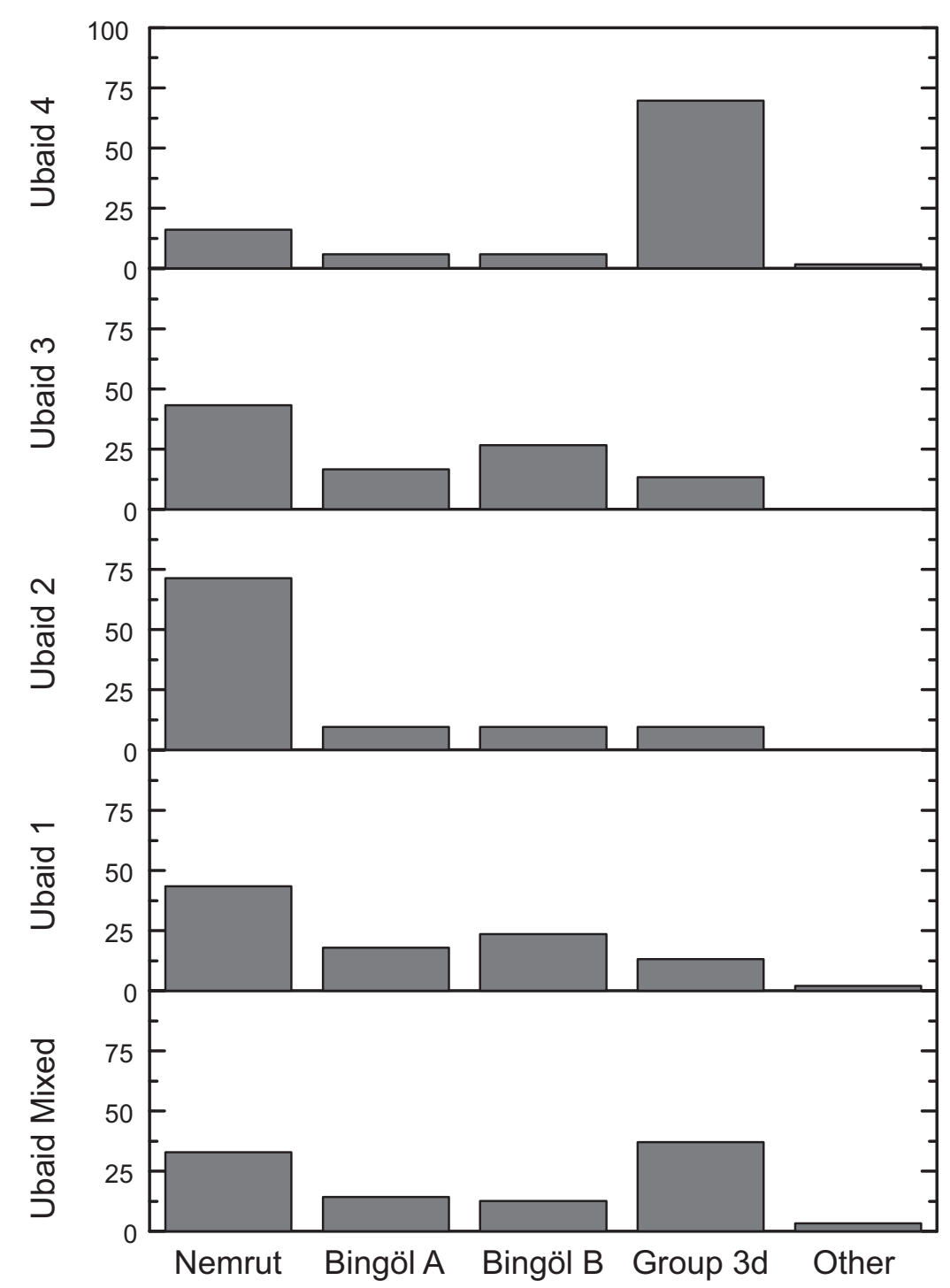

Fig. 8 


$$
040
$$




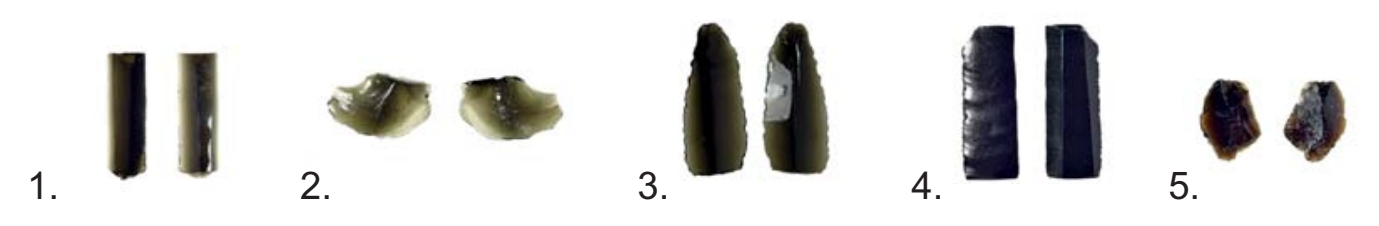

6.

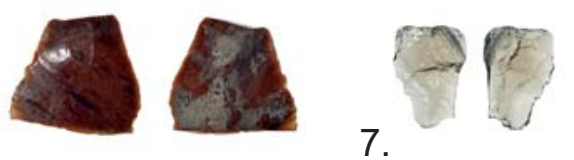

8.

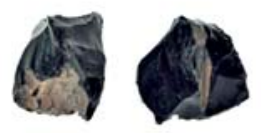

9.

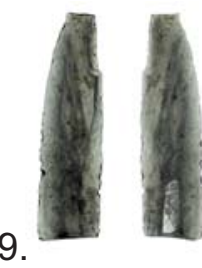

$2 \mathrm{~cm}$

Fig. 10 


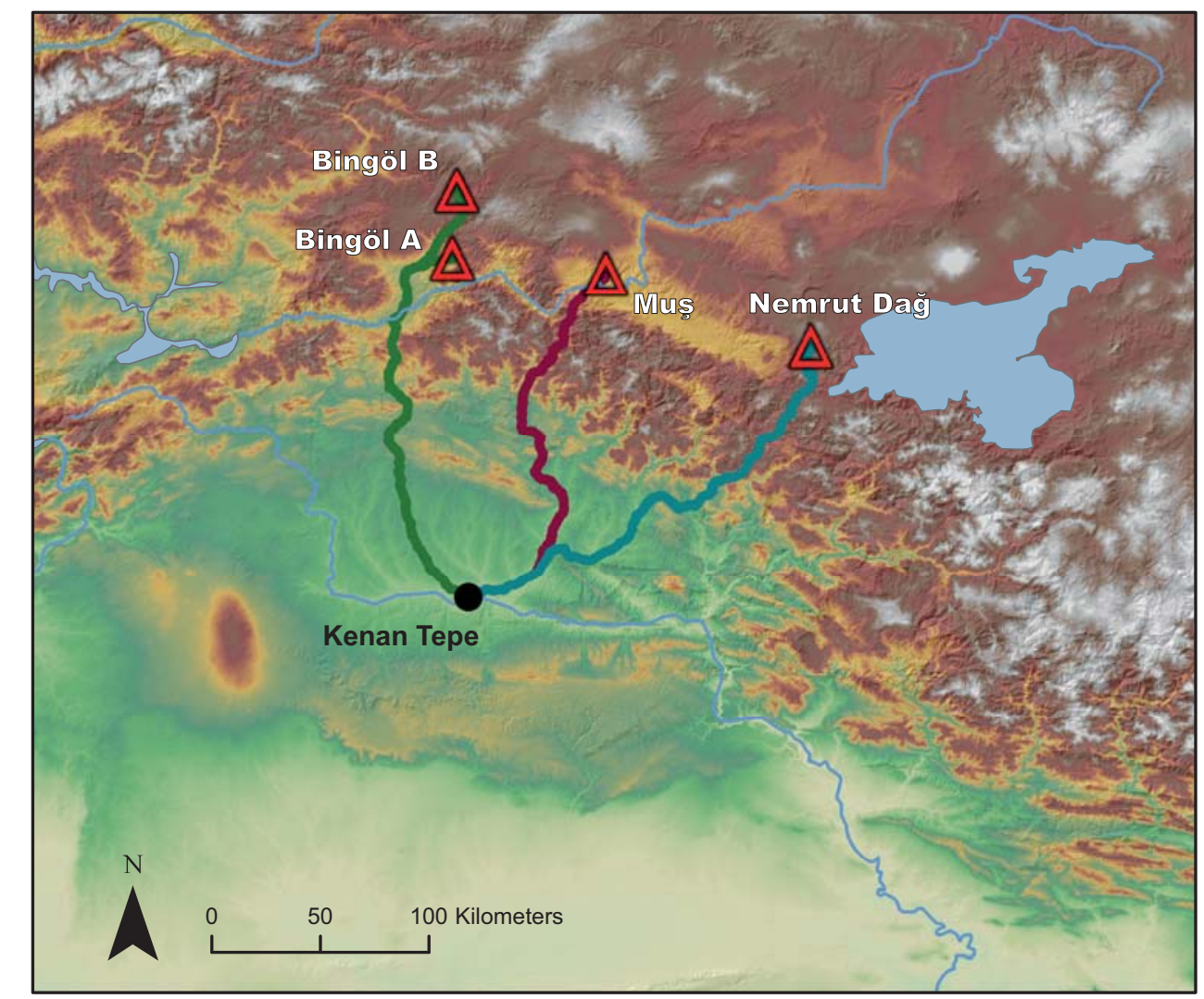

Fig. 11 